\title{
Mobile Internet Tariff Models: Technical or Political Decisions? A Costa Rican Case Study
}

\author{
Alexander Castro-Reyes ${ }^{1}$ and Gabriela Marín-Raventós ${ }^{2(\varpi)}$ \\ ${ }^{1}$ Doctorate Program in Government and Public Policy, University of Costa Rica, \\ San Pedro, Costa Rica \\ castro.alexander@gmail.com \\ ${ }^{2}$ CITIC-ECCI, University of Costa Rica, San José, Costa Rica \\ gabriela.marin@ucr.ac.cr
}

\begin{abstract}
We focus on the discussion about the proposal of shifting to a post paid mobile Internet tariff model based on usage, and its impact on universal use and service access for the poor sectors of the country. This proposal aims to address the problem of cellular data network saturation, by charging per downloaded kilobyte instead of allowing unlimited use. We analyze the position of important actors using the Advocacy Coalition Framework. The study reveals the absence of public policies on IT connectivity and infrastructure in Costa Rica. Based on the results, we conclude that the proposed change does not solve the saturation problem, but rather imposes limitations on access and usage for lowincome people, generating social exclusion and digital divide.
\end{abstract}

Keywords: E-readiness and ICT impact $\cdot$ Digital divide $\cdot$ ICT public policy

\section{Introduction}

By signing the Free Trade Agreement between the United States, Central America, and Dominican Republic in January 2004, Costa Rica begins a process of openness and organization of the telecommunications market, which had been a monopoly of the State until then. Our country embarks upon the adoption of laws and regulations that would shape the sector, among those the Telecommunications General Law and the Law on Strengthening and Modernization of the Public Entities in the Telecommunications Sector.

The first law mentioned above establishes mechanisms for regulating the sector, where as with the second, the Superintendency of Telecommunications (SUTEL) was created. This regulatory entity is responsible for promoting the efficiency, equity, quality, and coverage of the telecommunications services. ${ }^{1}$

Once the legislation required by the sector was approved, in 2011 the first two private mobile telephony carriers, Claro and Movistar, began operating [1]. They would compete with the state-owned telecommunications corporation called Costa

\footnotetext{
${ }^{1}$ SUTEL, http://Sutel.go.cr/pagina/quienes-somos.
} 
Rican Electricity Institute (ICE), previously sole provider of mobile telephony services in the country.

As a result, the number of cellular line subscriptions increased rapidly. Only two months after, Claro and Movistar had begun operations, the number of active cellular lines was 4.153.067, while it reached 7.111.981 in 2013, an increase of $58 \%$ compared to 2011. Opening of the cellular market resulted in high penetration of the service, with 151 subscriptions out of 100 inhabitants [2]. ${ }^{2}$ In 2014 the total number of subscriptions was 7.101.892, which rather shows that the upper limit of the market was been reached.

Furthermore, the perceptual participation of the operators in the market also changed. In 2011, ICE owned $90 \%$ of all mobile telephony subscriptions, whereas Claro and Movistar reached $3 \%$, respectively. By 2014, the total participation of ICE declined to $61 \%$, while Claro rose to $16 \%$ and Movistar $20 \%[2,3]$.

The trigger for these market changes was the supply of mobile cellular lines with unlimited access to Internet at higher speeds than those offered with fixed lines, along with facilities to access smartphones and the usage of datacards, both for prepaid and postpaid plans $[3,4]$.

Nevertheless, service operators soon showed saturation problems on their networks caused by a limited infrastructure and excessive growth in data traffic generated primarily by prepaid costumers who used their cellular phones as hotspot to connect small offices. Meanwhile, users pointed out of service problems regarding access, quality, speed, and coverage. ${ }^{3}$

In order to relieve the cellular network and discourage data consumption, in October 2012, SUTEL authorized operators to change the prepaid mobile Internet tariff of unlimited band to a rate based on downloaded kilobyte. They argued that the measure was taken to stop the "abusive use" of the cellular network [5]. However, it was until August 2013 that the operators decided to gradually accept the new tariff model, which, in the case of ICE for example, affected 3.8 million clients [6].

This measure generated discomfort in prepaid customers, mainly because the problems of access, quality of service and speed still persisted. Therefore, on March $28^{\text {th }}$ 2014, the Defensoría de los Habitantes (Ombudsman's Office) requested SUTEL a report on the planned measures to improve the quality and coverage of the data transmission service from the cellular network. Despite the pressure on this regard made by the Defensoría and by clients, on June 2014, SUTEL convened public audience to discuss, instead, a change in the postpaid mobile Internet tariff model to a rate per download, thus standardizing it to the one already existing for prepaid customers. ${ }^{4}$

The reason given by SUTEL was the saturation of the cellular network caused by excessive data traffic generated by $5 \%$ of postpaid users. They also argued that the tariff

\footnotetext{
2 De León [8] notes that there is a bias to misinterpret the number of connections with the degree of penetration of the cellular network and mobile Internet, as the trend in Latin America has been that users own more than one registered line, but they are not all active.

3 The saturation of the data network was a recurring topic discussed by the SUTEL [5] as well as coverage problems [6].

${ }^{4}$ La Gaceta No. 105, June $3^{\text {rd }}$, 2014, p. 75.
} 
model based on per kilobyte downloaded is applied internationally ${ }^{5}$, and that it should benefit consumers, because they would only pay for consumption and not for connection speed. This position was also supported by the previous Minister of Science, Technology and Telecommunications (MICITT) on June $10^{\text {th }}, 2014$ [7].

The rejection of this proposal was felt quickly in within Costa Rican Congress, the Ombudsman's Office, consumer organizations, business associations, and the academic sector. The opposition was due to the impact that this measure could have on the most vulnerable sectors of the country, where one important means of access to Internet is via cellular phone [8]. Meanwhile, Costa Rican Executive Power expressed its concern because the proposal could run counter to the country's efforts to universalize Internet access.

Some of the criticisms pointed out to the new tariff proposal were the lack of technical studies to back it, the use of outdated reports, the unresolved problems on the quality and the coverage of the service, the lack of information provided to the service's users, and the opinions expressed by SUTEL, viewed as in defense of the interests of the operators. This was highly criticized since SUTEL is supposed to be the public entity assigned by the Ministry of Science, Technology and Telecommunications (MICITT), to regulate the telecom market on behalf of Costa Rican citizens' welfare.

Due to public and social media pressures, and to legal actions that were brought by concerned actors, the audience requested by SUTEL was canceled and rescheduled for September 2015. It was canceled once more for similar reasons, and up to date, June 2016, its convocatory is currently being expected.

\section{Defining the Problem}

The proposal of changing the tariff model has generated concern in the country on account of the impact it would have on the most vulnerable social sectors, and on social exclusion and digital divide, this being the problem at hand. ${ }^{6}$

In Costa Rica, $20 \%$ of the total population (1,170,634 people) lives in poverty, especially in rural areas; where, in addition, the supply of fixed Internet services as DSL/ ADSL is limited or none-existent, based on estimations from the National Household Survey of INEC [11] and the State of the Nation Program [12]. Therefore, the proposal of changing the mobile Internet tariff model could generate social exclusion by raising the cost of access and usage of the service. It would affect the sectors with fewer resources, because they would be excluded from the intended benefits of Internet access as in the case of rural education since public programs use Internet post-paid services, which is discussed later. Another important issue is the intensity with which the service can be used. Providing access to users, but under conditions where they are unable to sustain the service due to monthly costs or have to restrict its use, is a way of creating uncovered digital divide.

\footnotetext{
${ }^{5}$ Limiting the consumption of data and establishing tariffs per kilobytes is an international trend currently in use [9].

${ }^{6}$ President of Costa Rica, Luis Guillermo Solis, said the proposal contradicts the country's vision of providing universal access to Internet [10].
} 
The issue being discussed here is relevant for the former reasons, and furthermore, because the value of Internet access lies not only in the access to information and knowledge, but also in helping people enhance their skills and improve their standard of living by having access to services in digital form, such as healthcare programs and education.

The problem is two-sided. It is important to find an integral and inclusive solution, one that would benefit not only users, but also operators allowing them to make their service profitable. Profitability is required by companies to be sustainable and to invest in better infrastructure and better technologies like 4 and 5G, and LTE, which bring advantages to its users.

The role of cellular or mobile service providers is crucial, because without them, it is not possible to provide Internet service to remote areas where fixed DSL or ADSL connections are non-existent. Mobile Internet has become a resource that can bridge the digital divide, but only if the cost is within the reach of people, and if the service is of high quality, coverage, and speed.

\section{Antecedents: What Has Happened in Other Countries?}

In 2009, the Organisation for Economic Co-operation and Development (OECD) [13] issued a report giving an account of the trend, at the international level, of the replacement of unlimited mobile Internet connections for models of charging per download. In that document, De León [14] points out that, because of the limited capacity of the radioelectric spectrum, in some OECD countries and in Latin America, the broadband service is sold by maximum transfer capacity and not by unlimited access.

The tariff structure change has resulted in a wide range of prices and service plans, in which the service provider charges per each additional Megabyte (MB), or drastically reduces transfer speed. Moreover, it is mentioned that the average monthly data consumption in the OECD countries is 4 GB per month, driven in part by the development of mobile applications that require larger amounts of traffic and high-speed networks (3G, 4G, WiMax, LTE). The study depicts that these applications have had a major impact in the mobile network data flow [14].

Meanwhile, in Latin America, mobile telephony operators have followed the international model of charging per download, instead of plans with unlimited capacity, offering a wide variety of tariffs, implementing fair use policies, or by charging the user the cost per every additional megabyte downloaded [14]. The adoption of this business model in the region responds to the rapid growth in mobile network data traffic, and the limited availability of radio spectrum frequencies due to saturation [15].

Hence, public policies in the region have been directed towards radio spectrum liberalization processes, and licensing to release the wireless network traffic. But beyond the spectrum availability, these policies leave out an important issue: the intensity with which customers can use the service [16]. According to De León [14] these de facto policies contrast with public policies undertaken by broadband leading countries, such as Australia, United States, and New Zealand. These nations, with greater vision, have directed their efforts to ensure universal access to the service and to improve the broadband infrastructure capacity. In order to do so, they have assigned significant public 
financial resources to develop broadband infrastructure and to create a smart grid of data transport (networks) that would allow the passage of high amounts of traffic. They do so as to give a boost to their own economies, reinforcing activities such as e-health, ecommerce, education, access to telecommunication services, and rapid Internet access.

De León concludes that “...the common denominator in these countries has been the creation of national broadband plans and the involvement of the highest authorities of the government in the strategic definition of such plans, injecting large sums of money to support these plans with a simultaneous vision to protect and to use market competition schemes, as well as the pursuit of efficiency and effectiveness of the plans." [14, p. 104].

As proposed by [17], the cost of postpaid mobile Internet service can be analyzed through its affordability. This measure has been established by the average price for postpaid plan, as a percentage of monthly GDP per capita. In the postpaid plan, the optimal threshold is $5 \%$ or less. It is a proxy of the proportion of income to be assigned to access the broadband service [17]. Based on 2014 statistics, Latin American countries with better affordability are Argentina, Chile, Costa Rica and Uruguay, with percentages below $2 \%$, relatively close to Japan, France, Italy, which are in the order of $0.6 \%$ [18]. In contrast, countries in Central America (El Salvador, Guatemala, Honduras and Nicaragua) and South America (Bolivia, Ecuador, Paraguay, Peru) were above the desired $5 \%$ threshold, which means that the service is not affordable for most population given its relative high price.

\section{Theoretical Framework}

To analyze the proposal of changing the postpaid mobile Internet tariff to a rate per download model, and its implications on universalization and access to the service, we have resorted to Advocacy Coalition Framework (ACF) of Sabatier and Jenkins [19, 20]. It aims to explain the change that occurs in public policies based on the role of ideas, beliefs, values, and ideology of the actors, who are actively involved in the discussion and political decision making. This framework has been used to analyze public policies in areas as public health, nuclear security, pollution air, water policy, climate change, oil and mineral, in the United States, Canada and Europe [20]. Also, it has been applied in Asia, Africa, Australia and South America, in metallurgical development policies, domestic violence, water policy, education, drugs and smoking control public policies [20].

Under this framework, the actors are grouped into a policy subsystem. This subsystem is understood as those governmental and non-governmental actors who interact around a particular policy issue, to dissuade decision makers and civil society about previously determined interests and beliefs [20,21]. The subsystem is composed by a wide variety of actors including governmental agencies and actors at different levels, legislators, bureaucrats, private organizations, academic community, associations, and individuals, where the cohesive elements are the ideas and beliefs shared around a policy issue or subject. The subsystem is expressed by the position actors adopt or by their discourse $[19,20]$. 
Such beliefs can be categorized into three levels: the deep core, the policy core and the secondary aspects [21]. The deep core refers to profound-rooted axioms shared by all actors, such as ideas about freedom, universal equity, and the type of government [22]. The policy core comprises the beliefs shared by the actors regarding a topic or issue of public policy. Finally, the secondary aspects refer to the technical and instrumental part of the implementation of a public policy. Secondary aspects are propitious to find room for negotiation, where quantitative technical information or qualitative arguments that are valid and solid enough can generate a shift in the policy debate, by indicating that the path taken thus far in policy making is not the best [23].

Our focus of analysis is the policy core, concentrating the discussion on a possible change for the postpaid Internet tariff model: from unlimited use to a rate per download. We are also interested on secondary aspects, which address how this model is intended to be applied, and how it would affect the sectors with lowest incomes. However, the analysis is based on the deep core.

In Costa Rica, the welfare state has its roots in the establishment of the Second Republic, in 1949. Since then, a universally recognized thought (Deep Core) is the State's obligation to ensure the welfare of all its citizens, and particularly, to ensure welfare of the most unprotected population. In consequence, the country has undertaken great efforts to improve the welfare for all its population, and especially for the most vulnerable sectors, by providing subsidized electricity, education, and health services throughout its territory.

With the emergence of Internet and its potential benefits, Costa Ricans started believing that the universal access to Internet generates social welfare and promotes socioeconomic development of the country's population. These beliefs were endorsed by ICE, public and leading provider of telecommunications services in the country. With market globalization, and the signing of the Free Trade Agreement, liberal groups with political power in the country promoted the idea that the market is the best mechanism for allocating resources, in opposition to tariff structures controlled by the State.

Thus, a questioning on how to organize the telecommunications sector in a context of trade openness and free market (policy core beliefs) arises, but also it would have to be possible to ensure digital equity and the welfare of the most vulnerable social sectors (deep core belief).

\section{Methodology}

Under ACF, it is important to recognize the beliefs, opinions, and positions of the actors involved in the discussion of the proposal of changing the tariff model and its impact on the most vulnerable sectors. To achieve this, we interviewed five key high-level actors that have participated actively in the discussion process of changing the tariff model. They belong to the academic, public, and private sectors and are recognized leaders in the information technology field. We selected them because their opinions represent their corresponding sectors.

The interviews were personal, consisting of eleven questions previously provided to respondents. The following aspects were addressed: (1) the reasons that motivated the proposal of changing the tariff model, (2) the potential effects on access and use of the 
service, (3) the social sectors affected and/or benefited with the intended change, and (4) the proposal improvements suggested. The actors interviewed were:

- Governmental Sector: Minister of Science, Technology and Telecommunications (MICITT).

- Private Sector: Vice-President of the Chamber of Information and Communication Technologies (CAMTIC).

- Academic Sector: Director of the Informatics Center of the University of Costa Rica (UCR-CI), and Director of the Information Society Program of the University of Costa Rica (UCR-PROSIC).

- Telephony Operators: Board Member of Costa Rican Electricity Institute (ICE).

Subsequently, their responses and issue perceptions were analyzed and filtered in a frequency matrix by topic and assumed position.

\section{Analysis}

The interviews were recorded and transcribed. The idea was to determine the topics upon which the various actors focused on and that can eventually be considered in the national discussion of the changing tariff model. Table 1 shows what each interviewee

Table 1. Results of interviews by category and dimension

\begin{tabular}{|c|c|c|c|c|c|c|}
\hline \multirow{2}{*}{ Dimension } & \multirow{2}{*}{ Category } & \multicolumn{5}{|c|}{ Referred to by } \\
\hline & & CAMTIO & $\begin{array}{l}\text { PROSIC- } \\
\text { UCR }\end{array}$ & CI-UCR & MICITT & ICE \\
\hline \multirow{7}{*}{$\begin{array}{l}\text { Telecommunications } \\
\text { infrastructure }\end{array}$} & Saturation of the mobile network & $\mathrm{x}$ & $\mathrm{x}$ & $\mathrm{x}$ & $\mathrm{x}$ & $\mathrm{x}$ \\
\hline & Reduced Internet infrastructure both fixed and mobile & $\mathrm{x}$ & $\mathrm{x}$ & $\mathrm{x}$ & $\mathrm{x}$ & $\mathrm{x}$ \\
\hline & Infrastructure's limited capacity & $\mathrm{x}$ & $\mathrm{x}$ & $\mathrm{x}$ & & $\mathrm{x}$ \\
\hline & Limited speed of the fixed network & $\mathrm{x}$ & & $\mathrm{x}$ & & \\
\hline & Improve the infrastructure of the fixed network & & $\mathrm{x}$ & $\mathrm{x}$ & & \\
\hline & Specific techno: Hotspot WLAN, Ethernet rings & $\mathrm{x}$ & $\mathrm{x}$ & $\mathrm{x}$ & & \\
\hline & Improve the use of the radio spectrum & & $\mathrm{x}$ & $\mathrm{x}$ & & \\
\hline \multirow{6}{*}{$\begin{array}{l}\text { Local market } \\
\text { conditions }\end{array}$} & Variety of proposal within each pre/postpaid model & & $\mathrm{x}$ & & & $\mathrm{x}$ \\
\hline & Different tariff models & $\mathrm{x}$ & $\mathrm{x}$ & & & $\mathrm{x}$ \\
\hline & Service quality & $\mathrm{x}$ & & & & \\
\hline & Revenue per person (RPU) & & & & $\mathrm{x}$ & \\
\hline & Differentiated tariffs & $\mathrm{x}$ & $\mathrm{x}$ & $\mathrm{x}$ & $\mathrm{x}$ & $\mathrm{x}$ \\
\hline & High consumption data & $\mathrm{x}$ & $\mathrm{x}$ & $\mathrm{x}$ & $\mathrm{x}$ & $\mathrm{x}$ \\
\hline \multirow[t]{7}{*}{ Social impacts } & Impact on the least able & $\mathrm{x}$ & $\mathrm{x}$ & $\bar{x}$ & & $\mathrm{x}$ \\
\hline & Increased costs to the less fortunate & $\mathrm{x}$ & $\mathrm{x}$ & $\mathrm{x}$ & & $\mathrm{x}$ \\
\hline & Difficulty to access Internet services & $\mathrm{x}$ & $\mathrm{x}$ & $\mathrm{x}$ & $\mathrm{x}$ & $\mathrm{x}$ \\
\hline & Increasing digital divide & $\mathrm{x}$ & $\mathrm{x}$ & & & $\mathrm{x}$ \\
\hline & Unequal access & & $\mathrm{x}$ & $\mathrm{x}$ & & $\mathrm{x}$ \\
\hline & Digital literacy & $\mathrm{x}$ & & & & \\
\hline & Tariff model is insufficient (not integral) & & $\mathrm{x}$ & & & $\mathrm{x}$ \\
\hline \multirow[t]{2}{*}{$\begin{array}{l}\text { The role of the } \\
\text { Government }\end{array}$} & $\begin{array}{l}\text { Vacuum in telecommunications and } \\
\text { infrastructure investment public policy }\end{array}$ & $\mathrm{x}$ & $\mathrm{x}$ & $\mathrm{x}$ & & $\mathrm{x}$ \\
\hline & Government's undefined position & & $\mathrm{x}$ & $\mathrm{x}$ & & $\mathrm{x}$ \\
\hline \multirow{3}{*}{$\begin{array}{l}\text { Causes for the } \\
\text { rejection }\end{array}$} & Proposed model based on weak technical reasons & $\mathrm{x}$ & $\mathrm{x}$ & $\mathrm{x}$ & & $\mathrm{x}$ \\
\hline & Proposed model based on weak financial reasons & $\mathrm{x}$ & $\mathrm{x}$ & $\mathrm{x}$ & & $\mathrm{x}$ \\
\hline & Proposed model based on weak comsuption analysis & $\mathrm{x}$ & $\mathrm{x}$ & $\mathrm{x}$ & & $\mathrm{x}$ \\
\hline
\end{tabular}


referred to. The "categories" were also ordered by dimensions, so as to help interpret the position of those interviewed.

After analyzing the data, five main topics addressed by the interviewees were identified: (1) the conditions of telecommunications infrastructure, (2) the local market conditions, (3) the social implications of the proposal, (4) the role of the government in the issue, and (5) the causes for rejection of the current proposal.

The most interesting discovery is that the responses posted by the Minister of MICITT are the least critical to the proposal, and they reflect no causes for its rejection (see Table 1). This position was also supported for his antecessor at MICITT. However, in both cases, their position was questioned by the Costa Rican Executive Power because the proposed change in tariff structure does not contribute to the national efforts to universalize Internet access.

In the following section we present the stated arguments in detail.

\subsection{Telecommunications Infrastructure}

All respondents agreed on the idea that the main problem of the saturation of the mobile data network in Costa Rica is due to the lag in the infrastructure that the country has. In the case of fixed infrastructure, some constraints were identified, such as the connection speeds that are offered and the reduced supply of ADSL lines, mainly in rural areas.

They also highlight that these limitations push users to make an intensive use of cellular data network, which is comparatively faster to acquire. This phenomenon leads the saturation in the mobile network. Moreover, they also diagnose that this saturation generates problems of access and quality, such as denial of service access, data traffic retransmissions, and latency. For the Director of CI-UCR, this situation is more common when mass activities are performed in specific areas of cellular coverage, or at large events like the Football World Cup, and where users' massive data traffic concentrates on a few antennas causing saturation in them and connections collapse. According to the Director of PROSIC-UCR, a similar situation occurs during traffic peak hours, where the use of geographic positioning applications, and data transmission in those hours, can cause problems of network congestion.

Under these conditions, the rate per download would go against users since much of the contracted plans (which define maximum service usage) would be consumed by congestion access problems and retransmissions. As a solution, the Vice-president of CAMTIC proposes to liberalize the service and to create cellular aggregation rings, while the Director of PROSIC and of the CI-UCR point out the need for cellular network planning and for an improvement on the use of the radio spectrum.

\subsection{Local Market Conditions}

All interviewees agreed that the limited supply of differentiated mobile Internet service plans is due to the lack of real competition among service operators, for rates are set administratively by the SUTEL. Therefore, all mobile Internet plans in the market are in essence very similar; thus users choose the operator based on other criteria, such as coverage or relative quality of the service, as stated by the Director of CI-UCR. 
The Minister of MICITT holds that part of the problem is due to the low incomes that the operators receive per user. He argues that the revenue per user is relatively low in Costa Rica. He stated that low income does not allow operators to become profitable and invest in infrastructure, making it necessary to find other forms of charging. Regarding this point, the Director of CI-UCR and the Board Member of ICE recognized that the income of the operators has lessened as costumers use the Internet to send text messages and make online calls, which constantly diminishes the use of traditional voice and text services. However, the Director of CI-UCR indicated that profitability is constrained also by high costs. He depicted that transportation problems and efficiencies mainly occur in $3 \mathrm{G}$ networks, while $4 \mathrm{G}$ networks are more efficient since all the voice, text and data traffic is encapsulated, representing a lower cost to operators.

Furthermore, they all recognized the need to find new payment forms that would allow service carriers to keep operating, but under different conditions: liberalizing the market and stimulating competition, but with formulas that do not exclude vulnerable social sectors from Internet service access.

\subsection{Social Implications}

A recurring concern in the discussion of the model is the impact that this proposal can have on the most vulnerable population and on government programs aimed to these sectors, such as education.

As stated by the Ministry of Public Education (MEP), this measure "would affect 1,574 public schools across the country, since they have access to the Internet via datacards that MEP must pay monthly as part of postpaid plans, and which are the only tool to enter the web that these institutions can count on" [24]. MEP also remarked that the tariff per download would affect the online services that the institution offers to students and parents, such as information on school calendar, practices to get ready for the nationwide baccalaureate exams, and the program "The Professor in your House." Many students make inquiries from the cellular phone, especially those in areas outside the Greater Metropolitan Area, and where there are not fixed telephony services [24]. About this particular, the Director of PROSIC-UCR considers important for operators to generate alternative tariff models addressed to the lower income citizens. The Vicepresident of CAMTIC, the Director of CI-UCR, and the Board Member of ICE had similar positions. For them, the tariff models that are offered should ponder the target population to which the service is addressed, it being from rural or urban areas. They all recommend that tariff models should consider different thresholds rates.

\subsection{The Role of the Government}

The interviewees pointed out the absence of a clear public policy, with corresponding financial support, regarding infrastructure and telecommunications. Such absence is shown in the undefined position the Government has had in relation to the discussion of the proposed tariff model. Most of them accounted that, while in 2014 the Minister of MICITT expressed support for this proposal, the Executive Power affirmed that it set aside the country's vision of universal access to the Internet. Furthermore, at this point 
it is worth mentioning the opposition expressed in public media by the Minister of Education due to the impact this could have on the programs and services offered by the institution, especially in rural zones or poor urban areas. As the Vice-president of CAMTIC indicated, the Government's lack of definition on this issue is evidenced by not taking into consideration its effects on other plans or state programs.

The solutions suggested by interviewees stressed the need of a greater participation of the Government on this issue, by developing clear policies in infrastructure, digital literacy, and development of mobile applications to take advantage of these technologies, lowering the cost of smartphones, and liberalizing the telecommunications market.

\subsection{Causes for the Rejection of the Current Proposal}

The interviewees agreed on the perception that the rejection of the tariff change proposal is based on: the lack of technical support to justify the change, the price suggested per kilobyte, the limit threshold to start charging per kilobyte, and the arguments included on users with excessive consumption.

According to SUTEL, the "abusive" consumption by $5 \%$ of postpaid users saturates the network, so it is necessary to charge per download in order to relieve network congestion, and they propose that the price per kilobyte downloaded be $\phi 0.0076$ once you exceed $500 \mathrm{MB}$ consumption [25]. Four out of five interviewees consider the lack of updated and rigorous technical information one of the main weaknesses of the proposed plan. They remarked that the proposal does not present technical studies to identify the users with "abusive" consumption, or even does not define what is regarded as "abusive" consumption. Neither does it provide data about the calculation of the price per kilobyte, but it sets a consumption limit of $500 \mathrm{MB}$, considering it a suitable average. These arguments are classified as erroneous by the representative of CAMTIC and the Director of CI-UCR. They argued that even though there is a high consumption by some users, the proposal does not clearly identify who they are. They claimed that in the market there certainly exist users with high consumption needs; therefore, these costumers should not be pointed out as "abusive", but rather they have to be provided tariffs and plans that suit their consumption habits. The importance of defining and implementing fair use policies is also stressed by all.

Both the Director of CI-UCR and the Board Member of ICE state that there are users with different consumption necessities that require connectivity plans that would meet their needs. Hence, it is important to have competition in the sector that would provide a variety of connectivity plans: by consumer, by regions, or by time slots, lowering the service in slots where the network has less traffic, and thus, balancing it. It is clear that users have different consumption habits, so it is beneficial to offer differentiated plans or rates.

\section{Conclusions}

From the observations made by the interviewees, it can be concluded that the current proposal of changing the postpaid mobile Internet tariff model is counterproductive to people with fewer economical resources and from rural zones, as it establishes 
restrictions on access to the service and on public education programs. It mainly affects users from rural areas. The proposal seeks, wrongly, to solve through price obstacles, problems regarding infrastructure, access, coverage, and quality. According to the interviewees, these problems need to be addressed differently, so they propose other solutions.

In order to do so, they pointed out the necessity to promote a framework for competition and liberalization of the sector that may lead to differentiation and heterogeneity through tariff customized models for consumption, speed, geographical area (rural/ urban), and time slots, and the implementation of fair use policies. This requires studies of average consumption on prepaid and postpaid data to avoid speculation on consumption and price per kilobyte, as the current proposal is been perceived.

In terms of service, the proposal of shifting the payment model to use parameters is accepted as long as it brings service quality and coverage, as well as state subsidies for users with fewer resources and with reduced options of Internet access.

Most sectors claim that the infrastructure of the fixed network must be improved, especially in rural areas, by offering high-speed ADSL lines and the implementation of wireless access, to make a better use of the radio spectrum. Public policies that promote investments in network infrastructure, socioeconomic development and digital equity are critical. Some bet on promoting the liberalization of the sector and fostering free competence, and influencing on cost reduction of smartphones and mobile devices with cellular network access such as tablets. However, this must not be enough. It is also essential to pursue public policies that promote digital literacy and the development of citizen centric mobile applications, to empower vulnerable communities. Maybe the solution comes from incorporating successful experiences of other countries, but customized to our environment and need.

\section{References}

1. PROSIC: Hacia la sociedad de la Información y el Conocimiento. Programa de la Sociedad de la Información y el Conocimiento. Universidad de Costa Rica (2012)

2. SUTEL: Estadísticas del Sector de Telecomunicaciones: Informe 2014. Superintendencia de Telecomunicaciones (2014)

3. SUTEL: Estadísticas del Sector de Telecomunicaciones: 2010-2012. Superintendencia de Telecomunicaciones (2013)

4. Mercedes, A.: Contratos de Internet móvil se dispararon a un millón en 2 años (2013). http:// www.nacion.com/nacional/Contratos-Internet-movil-dispararon-millon_0_1364263614.html. (cited 5 Sept 2013)

5. Herrera, M.: SUTEL avala cobro de Internet por descarga (2012). http://www.nacion.com/ nacional/comunidades/SUTEL-avala-cobro-Internet-descarga_0_1299870057.html. (cited 18 Oct 2012)

6. Agüero, M.: Internet móvil: talón de Aquiles de operadoras (2013). http://www.nacion.com/ nacional/comunidades/Internet-móvil-talon-Aquiles-operadoras_0_1347065638.html. (cited 11 Jun 2013)

7. Fallas, G.: Ministra de Ciencia y Tecnología respalda cobro por descarga para Internet móvil postpago (2014). http://www.ameliarueda.com/nota/ministra-de-ciencia-y-tecnologia-respaldacobro-por-descarga-para-internet-. (cited 10 Jun 2014) 
8. Quesada, J.: Diputados consideran que cambio en cobro de Internet celular podría ser ilegal (2014). http://www.teletica.com/Noticias/56069-Diputados-consideran-que-cambio-en-cob ro-de-Internet-celular-podria-ser-ilegal.note.aspx. (cited 9 Jun 2014)

9. Sancho, M.: Gobierno apoya propuesta de cobro por descarga de Internet (2014). http:// www.crhoy.com/gobierno-apoya-propuesta-de-cobro-por-descarga-de-internet-w917m0x/. (cited 10 Jun 2014)

10. Fallas, G.: Cobro por descarga en internet móvil postpago conlleva un "mensaje contradictorio" (2014). http://www.ameliarueda.com/nota/cobro-por-descarga-en-internetmovil-postpago-conlleva-un-mensaje-contradictorio. (cited 13 Jun 2014)

11. INEC: Encuesta Nacional de Hogares Julio 2014: resultados generales. Instituto Nacional de Estadística y Censo (2014)

12. Programa Estado de la Nación en Desarrollo Humano Sostenible: Vigésimo primer Informe Estado de la Nación en Desarrollo Humano Sostenible (2015)

13. OCDE: Communications Outlook 2009. Information and Communications Technologies. Organización para la Cooperación y el Desarrollo Económico (2009)

14. De León, O.: Panorama de la banda ancha en América Latina. CEPAL (2010). http:// www.cepal.org/es/publicaciones/3833-panorama-de-la-banda-ancha-en-america-latina-2010

15. Prensario Internacional: El Fin de la Banda Ancha Ilimitada (2011) http://www.prensario.net/ 458-El-Fin-de-la-Banda-Ancha-Ilimitada.note.aspx. (cited 24 Jun 2011)

16. Flores-Roux, E.: Banda ancha móvil: la urgencia de acelerar su despliegue en Banda Ancha. In: Jordan, V.; Galperín, H.; Peres, W. (eds.) CEPAL, pp. 136-148 (2013)

17. CEPAL: Estado de la Banda ancha en América Latina y el Caribe (2015). http:// www.cepal.org/es/publicaciones/38605-estado-de-la-banda-ancha-en-america-latina-y-elcaribe-2015

18. CEPAL: La nueva revolucion digital. De la Internet del consumo a la Internet de la producción (2015). http://www.cepal.org/es/publicaciones/38604-la-nueva-revolucion-digital-la-inter net-consumo-la-internet-la-produccion

19. Sabatier, P.A., Jenkins-Smith, H.C.: Policy Change and Learning: An Advocacy Coalition Approach. Westview Press, Boulder (1993)

20. Sabatier, P.A., Jenkins-Smith, H.C.: The advocacy coalition framework: an assessment. In: Theories of the policy process, pp. 117-165. Westview Press, Boulder (1999). http:// www.ucdenver.edu/academics/colleges/SPA/FacultyStaff/Faculty/Documents/Weible\%20and \%20Sabatier\%20ACF\%20chapter\%20in\%20Fischer\%20et\%20al.\%202006.pdf. (2016)

21. Hann, A., Sabatier, P.: Belief systems and public policy. Politics 15(1), 19-26 (1995)

22. Weible, C., Sabatier, P., Lubell, M.: A comparison of a collaborative and top-down approach to the use of science in policy: establishing marine protected areas in California. Policy Stud. J. 32(2), 187-207 (2004)

23. Sabatier, P.A., Weible, C.M.: The advocacy coalition framework. In: Sabatier, P.A. (ed.) Theories of the Policy Process, pp. 189-220. Westview Press, Boulder (2007)

24. Avendaño, M.: Cobro de Internet móvil por descarga afectaría a 1.574 centros educativos públicos (2014). http://www.ameliarueda.com/nota/cobro-de-internet-móvil-por-descargaafectaria-a-1.574-centros-educativos-p. (cited 16 Jun 2014)

25. SUTEL: Convocatoria a audiencia pública, La Gaceta No. 192 (2015). https://SUTEL.go.cr/ sites/default/files/audiencias/gaceta_convocatoria_audiencia_publica_28_oct_0.pdf 